УДК: 7.032:729.7

ББК: 85.14

A43

DOI: $10.18688 /$ aa199-1-9

A. I. Larionov, A. P. Frolov

\title{
Some Observations on the Mosaic Pavements in Lod, Huqoq and Wadi Hamam
}

While being exemplified by an infinite variety of artistic techniques, pictorial means and compositional plans, mosaic panels of Late Antiquity share some inherent unity manifesting through their subject matter and the similarity of typological traits still present in the surviving monuments ${ }^{1}$. This makes us turn, time and again, to the problem of identifying the dates and locations of their creation. At present, experts in the field are in possession of an extensive arsenal of modern dating methods that broaden the scope of research dealing with Antique mosaics. In cases when the panels were recovered from their authentic underlayer, following the prescribed procedure of due description and documenting, the approaches based on studying the stratigraphic context of the mosaic pavement gain major importance. The latter is greatly supported by the data from the related fields and precise research methods.

Of particular interest are the facts concerning the new finds unearthed in Lod (Israel). The information is presented in the publication coauthored by Rebecca Piovesan and Lara Maritan (both from the University of Padua), and Jacques Neguer (The Israel Antiquities Authority) [18, pp. 203-208]. Using microstratigraphy, fluoroscopy and chemical analysis of materials employed in the Lod pavements, they concentrated on the technological aspects of assembling mosaic panels.

In the current article we will focus on three famous pavements found in Israel: the above mentioned panels from the monumental edifice in Lod (a city some $15 \mathrm{~km}$ south-east of TelAviv) $[1]^{2}$ and from the Galilean settlements of Huqoq [10, pp. 61-131 $]^{3}$ and Wadi Hamam [12; 15] nearby the Lake of Kinnereth (Sea of Galilee), discovered respectively in 1996, in 2012 and in 2007 (excavations continue up till now).

Though stylistic analysis remains among art historians a leading means for dating artifacts, some experts regard it as subjective [12, p. 177, n. 191]. This opinion is based on the fact that,

\footnotetext{
1 The authors express their deep gratitude to N. C. Jijina, the first reader of this article, as well as to N. A. Nalimova and T. P. Kisbali, whose useful remarks and advice we tried to take into consideration. Additionally, we would like to thank Dm. Yu. Bragilevsky — translator of this article.

2 With a considerable degree of certainty, the now famous mosaic pavement spotted in 1996 in Lod by the expedition, with M. Avissar (The Israel Antiquities Authority) at its head, should be attributed to the cluster of workshops of Galilee, cf.: [1, pp. 169-172]. The northern section of the pavement was exhibited at the greatest museums of both the USA and Europe. In 2014-2015 it was put on display at the Hermitage (Ill. 14). Also see: [9, pp. 82-85].

The annual reports of the expedition in Huqoq are published in the electronic journal Hadashot Arkheologiyot (Excavations and Surveys in Israel: 2011, 2012, 2013, 2014, 2015, 2016, 2017). Available at: http://www.hadashot-esi.org.il/reports_list_eng.aspx (accessed 04 September 2018).
} 
following logic alone, researchers might find themselves facing issues hard to resolve, as the application of only this dating method inevitably imposes restrictions on their free choice of ways of analysis.

Nevertheless, we should not underestimate the potential inherent in analyzing stylistic features of figurative images, since it is one of the tools employed in interdisciplinary research. Thus, in addition to studying the aspects of style, it covers the techniques of setting the mosaic panels. In our case, the objects to be considered are certain images of fish, grouped according to their significant similarity with each other (in the cases shown, almost identical). In addition, we would like to make it clear that to us, practicing mosaic artists, technology is the most important point [8], especially the specifications of mosaic pavements, along with the definitive principles and technical details concerning the structure of mosaic foundations.

The overall majority of the panels are fully or partially devoted to picturing inhabitants of the sea depths. The entire Mediterranean oecumene, be it the mainland or islands, abounds in decorative mosaics illustrating marine themes. The famous mosaic panels from Rome and its provinces in Central Europe, Northern Africa, the Eastern Mediterranean and Asia Minor feature subjects with a variety of aquatic creatures. In the historical and cultural sense, mosaic panels depicting fish are of interest not so much because they so skillfully convey the matching colors and plasticity of the naturally decorative underwater inhabitants, but because of the hidden meanings and symbols they were originally associated with, image of fish being regarded as one of the key apotropaic symbols in the world art, including mosaics.

In his essay on the Roman mosaics in Tunisia, the well-known French journalist, translator, writer and publicist G. Fradier ${ }^{4}$ remarks that fish in a heraldic posture alone can often constitute the theme of a pavement or wall mosaic which decorated and protected the threshold of a bedroom, and that with a shell it becomes a phallic symbol [5, p. 26], one of the oldest in world art history. Fish is also a symbol of water, of life and fertility. It lives in the depths of the sea and absorbs there the powers of the deep where all life is continuously engendered and regenerated.

Ancient mosaic artists achieved amazing results, creating a kind of encyclopedia of marine fauna. In their works, species of fish inhabiting a particular area were so easily recognized that they could serve as a visual aid for a fisherman. Acknowledging symbolism and meaning as important aspects of the fish imagery, we should not consider it incidental that it is rarely depicted generalized, almost always being a specific type of fish. Intricate figurative images of fish found in pavements within sacred and secular buildings seem to be almost documental in their imitation of realistic appearances and conformity of species to nature. At the same time, mosaic panels representing the very same underwater fauna, executed in different regions, do not fully resemble each other. It is more than likely that these differences reflect the diversity of artistic preferences towards form shown by the artisans of particular regional mosaic workshops.

Such preferences can be exemplified by pavements in the ancient synagogues of Galilee ${ }^{5}$. Comparison of individual mosaic fragments found in the region in recent years allows us to

\footnotetext{
$4 \quad$ Member of Unesco from 1949, Director of its Press Department, Head of the UNESCO missions to Mali and Sierra-Leone; in 1985 - in charge of the Carthage-Tunisia regional development project.

$5 \quad$ For detailed survey of discoveries and recent archeological research on Israeli Synagogues, including their architecture and interior decoration, as well as mosaic pavements, along with the analysis of the religious symbolism cf. [6].
} 
suppose that for a lengthy period of time a mosaic center might have existed in this part of Israel. The works that this center produced for various architectural structures have much in common in their subject matter, composition, artistic techniques and skills of execution. Meanwhile their stylistic treatment is quite unusual for what was generally deemed typical of the Mediterranean ${ }^{6}$.

This becomes particularly noticeable if we try to choose among the images of the aquatic creatures those that can be grouped together on the basis of their similarity and as being different from other species. We are talking of a particular image of fish, whose breed is not yet precisely defined, and also about a specific way it was depicted. Similar stylistic treatment can be traced in 3 sections in the Northern block of the Lod pavement, and also in mosaics from Huqoq and Wadi Hamam. Our assessment should be viewed in connection with the evaluation of the dating of these mosaic panels. Researchers of Israeli mosaics assume that the panels should approximately be defined as having been produced between the late $3^{\text {rd }} /$ early $4^{\text {th }}$ and the early $5^{\text {th }}$ century A.D. ${ }^{7}$ As to the precise dating, here the opinions of the scientists (Jodi Magness, Uzi Leibner, Shulamit Miller) in charge of both Huqoq and Wadi Hamam excavations differ.

The exact analogies of the same version of this "ichthyologic" form are unknown in other parts of the Mediterranean, yet they are easily recognizable because of the unique style used in the area for depicting fish (Lod - Ill. 11. and Huqoq - Ill. 12.). These creatures differ from all other fish due to their large size; their almost identical toothy, gaping jaws, their tense and curved bodies, as if ready to attack the prey. Powerful outlines composed of several rows of darker tesserae help distinguish them against the light background. Beads of white tesserae convey the sheen of their scale, impressive colour combinations of coldish pearly tints stand out against ochre inserts or bands running along the whole body. The aggressiveness of the fish in the panels from Lod and Huqoq differs in meaning and its dramatic objective: in one case it should be explained by the generalized feeling of danger concealed in the sea abyss or presented by its inhabitants (Lod), in the other the divine punishment for mistreating the people of God (the miraculous Passage through the Red Sea: Huqoq, Ill. 13 and Wadi Hamam). Possibly, reproducing the species of fish was not the task of the artisans. Their fish are just fish, a generalized type devoid of any traits of a specific breed.

Meanwhile, we would like to note that, though we could find no direct correlations between the natural species and the fish in question, the ichthyologic identification was performed by the scholars researching the monuments themselves. The genus identification of the fish from the Lod pavement is offered by C. S. Lightfoot in the article available on the Metropolitan museum site [13], also J. Magness and her colleagues defined, though with reservations, a few species from the Huqoq discovery [14, p. 105].

\footnotetext{
6 Similar conclusions as to the existence of some distinct kind of an architectural unity within Galilee, which formed around the middle of the $3^{\text {rd }}$ century and lasted for at least 150-200 years, have been reached by the head of the Hellenistic Galilee Project, U. Leibner, an archeologist from the Jewish University in Jerusalem [12, Ch. 3; 11, p. 402].

The date pointed to by C. S. Lightfoot for the Lod mosaics is early $4^{\text {th }}$ century A.D. [13]; the antique pavements of the Huqoq synagogue, unearthed during the 2016-2017 excavations, span a considerable time period from $4^{\text {th }}$ to $5^{\text {th }}$ century A.D., while the earliest ceramic finds from Wadi Hamam date back to third or fourth decade of the $2^{\text {nd }}$ century A.D. [16, pp. 409-410].
} 
The monumental edifice of the synagogue at Huqoq features excellent mosaic pavements with unique or rarely seen Biblical or Apocryphal subjects. Almost like every other synagogue of the same period, they bear the imprint of Hellenic-Jewish artistic syncretism. However, U. Leibner, for example, points to the obvious differences in everyday culture of the Jewish and pagan population in the lands being under the rule of the Hasmonean dynasty and beyond in late Hellenistic time [11, pp. 399-400] ${ }^{8}$. One of the two mosaic panels depicting various types of fish is devoted to the miraculous Passage through the Red Sea. In the pavement devoid of pictorial depth and misallied vertically, among the broken and upturned carts, horses and Egyptian soldiers wallowing helplessly in the water, some monstrous sea creatures dash randomly, escalating chaos, turmoil and the premonition of disaster. In the field report of J. Magness [14, pp. 104, 105, fig. 40] who was in charge of the expedition to the Huqoq settlement, it is stated that black tesserae framing the silvery underbelly of the fish might be interpreted as its shadow [14, p. 105]. Yet, such an observation may be correct only if the fish is placed on the table top or shown against the sandy sea bottom lit by the sunrays through the thickness of the clear water, resembling what would now be called a still-life.

In this case, the black contour, in our opinion, is meant to strengthen the composition and make the dramatic constituent more apparent. Though, we admit, numerous approaches towards representing falling shadows cast by living beings or objects exist (for example, the "asarotos oikos" panels [4]).

A different panel from Huqoq shows a terrifying scene of the Prophet Jonah being successively devoured by three giant sea monsters [14, p. 111, fig. 45 $]^{9}$. Nearly all the other characters of the narrative are engaged in their routine activities, paying no attention to the perishing prophet; only the captain of the vessel, rushing around the deck, is trying to save him. Here, Israeli scientists managed to discern about a dozen different species of marine fauna, some of which they were able to identify.

Two mosaic panels depicting the miraculous Passage through the Red Sea and the Construction of the Tower of Babel from the synagogue in Wadi Hamam settlement reiterate the equivalent subjects from the Huqoq pavement [12, p. 165, fig. 4.32; p. 166, fig. 4.34 - "Passage through the Red Sea": panel 12]. The unprecedented similarity demonstrated by the manner of execution allows us to assume that the work in both synagogues might have been carried out by the artisans from the same mosaic center, and possibly at the same time. Even though the Red Sea mosaics from the Wadi Hamam synagogue suffered considerable damage, an important element showing the fish of the kind we are concerned with miraculously survived in the lower part of the composition. The expressive plasticity and style of the mosaic composition bring it closer to the pavements in Lod and Huqoq.

The already mentioned publication by R. Piovesan and her coauthors describes the technical and technological process of making a mosaic pavement in detail, yet, we would like to clarify the step by step progression of the work. With this in mind we will turn to the technicalities of mosaic setting, taking into account the fact that among the mosaic artists

For some cases of these complex cultural interrelations see also $[17 ; 19]$.

A similar subject can be found in the mosaic panel of Tunisia, discovered in 1902 in Bizerta, and at present is shown the Bardo National Museum. Its provenance, though, is uncertain. 
certain terms and abbreviations are in use. Some 50 years ago the International Association for the Study of Ancient Mosaics [2] adopted conventional combinations of letters and numerals to mark various techniques of setting decorative borders that frame figurative subjects and motifs. Among the first scholars to propose the concept of a systematic work on the project was Irving Lavin [10]. The availability of this lucid and very logical system allows us to utilize it, while discussing the pictorial aspects of the pavements in question, which to some point might have helped us shorten the descriptive account in this part of the article. However, it seems to be the case when, for the sake of clarity, it makes better sense to resort to a verbal description.

In the same room of the Hermitage, where the northern block of the Lod pavement was put on display as part of a loan exhibition, some fragments of ground with traces of color impressions left by tesserae once imprinted into it could be seen. These colorful traces evoked no less curiosity from the viewers than the mosaic panels themselves. Undoubtedly, the important question of how the pigments survived in the hollows of the under-layer calls for technical explanation. In this respect some research conducted by the Israeli scientists should be regarded as useful.

Getting the leveling layer (nucleus) ready to be covered with an underpainting involved using lime, this guaranteed reliable adherence of the pigment particles to the surface of the nucleus. The pigments then had time to set and remain in the nucleus layer without being glued to the tesserae. On top of the painted polychromic "sinopia"10 the mosaic artists would lay a thin coat of fresh lime putty over the pre-wetted nucleus to insert the mosaic modules into it $[7, \mathrm{p} .446]$. The water would slightly soften the underlying layer of the nucleus. This was sufficient for the tesserae pressed into the fresh binding matter to imprint the pigment onto it. Being squeezed from under the modules and filling the joints between the tesserae, the fresh putty allowed ample space for grouting. Usually, the area covered by the supernucleus would equal the expected daily production rate (giornate [18, Introduction and p. 204]) of an artist.

The statement that the mosaic underpainting is a phenomenon unique for antique mosaics needed verification. With this in mind, we conducted a series of experiments in 2015 when, working on the fundamentals of the mosaics with our students, we attempted at reconstructing the process of setting mosaic panels, using as subject matter the images of fish from the Lod pavement. We tried to avoid paper, except for designing cartoons, so that the students would learn the techniques of working with brushes and pigments. In ancient times the underpainting for the mosaic setting was done as a fresco, as paper was not available, while papyrus or parchment was too costly. On top of the under-painting, when the surface was almost dry, fresh binding solution was then applied in small patches, so that the major image would remain intact for as long as possible. Then the entire visual plane was gradually covered with mosaic modules. Nearly all the students assembled the mosaic panels within one day. From this experiment we concluded that making new discoveries of frescos hidden under the layer of tesserae is only a matter of time. In this connection, the value of the fact that the Israeli restorers have developed a technique allowing the removal of mosaic panels from their backing practically without any damage is hard to overestimate.

10 This term can be accepted with a degree of caution, as the use of the word "polychromic" to describe a monochrome pigment is not quite correct. 
We would also like to expound upon the scheme of the stratigraphic section for the mosaic foundation in Lod [18, p. 205, fig. 4] ${ }^{11}$, presented in the article by R. Piovesan et al., where the stippled line indicates some loose ground under the lower layer. Though the fact of its not being compacted is not mentioned, it is deduced from the way it is shown. Besides, the caption explaining the arrangement scheme informs the reader that the external signs point to the classical stratigraphy typical of Roman mosaics, which consists of a thick bottom layer composed of gravel and clay to smooth the roughness of the earth, and to provide the hard foundation of the floor, followed by a layer of coarse mortar and covered, in its turn, by "supernucleus" (a thin coat of binding matter) bearing sinopia, where tesserae were set [18, p. 205].

K. Dunbabin presented in her definitive monograph on the art of Antique mosaics a convincing illustration of a stratigraphic section of the mosaic foundation [3, Part II. Ch. 16, p. 282, fig. 288]. The "Zeno Archive" [3, Part I. Ch. 2, p. 23, n. 16] - a fragmented papyrus, found among other documents, with a contract for making mosaic panels to decorate a swimming pool in Fayum, should also be mentioned, as the document proves that in the mid- $3^{\text {rd }}$ century B.C. the mosaic work regulations existed. One of the authors of the present article once participated in making a decorative mosaic fountain: the way of building the foundation layers was hardly different from what had been employed in antiquity. Decorative floors with warm air flows underneath can be considered exceptions from the rules, but we do not intend to discuss them here.

In accordance with the classical stratigraphy of Roman mosaics, the earth to be paved was thoroughly leveled and rammed before the initial layer of the foundation could be put to avoid the possible subsidence of the finished pavement. Then rough boulders were forced into the compacted earth serving as a durable under-layer, these were then covered with slurry. This layer called statumen was not only the base for the solid foundation, but also gave protection from water (the diagram for the stratigraphic section of the Lod pavement terms it Gravel + Clay). When this crucially important foundation became slightly drier, hydraulic lime was applied to it with an addition of rubble, thus forming a layer of rudus (i.e., rubble). Next, a smoothing layer of nucleus was spread over the rudus. Its name is explained by the fact that nucleus was located between the upper and the lower layers of the pavement. However, the stratigraphic section presented in the article by R. Piovesan and her coauthors lacks nucleus, so the term super-nucleus ${ }^{12}$ (being above the nucleus) loses part of its meaning. The main purpose of having this layer, which we call "screed", was to prepare a flat surface for the artist to put a polychromic under-painting so that it could serve as the ground where the mosaic artists installed tesserae over the nucleus (Ill. 15).

The above clarifications, necessary in our opinion, are in no way intended to underestimate the value of the research conducted by Israeli scientists. We would also be delighted to see other examples of employment of those methods of saving and preserving mosaics that were used by the associates of M. Avissar in the process of lifting the pavement and opening the ground under it in Lod.

\footnotetext{
11 The permission to use the fragment has been obtained on September 11, 2018 by the courtesy of J. Neguer, one of the authors.

${ }_{12}$ The introduction of the term "super-nucleus" should be considered as useful when it concerns antique mosaic work.
} 


\section{Conclusions}

In agreement with the opinion of $\mathrm{U}$. Leibner, it is possible to consider it a proven fact that during the $3^{\text {rd }}-5^{\text {th }}$ centuries A.D. a mosaic workshop existed in Galilee, which preserved in its works the artistic traditions of the Mediterranean.

Due to the latest discoveries in Lod, Huqoq and Wadi Hamam, the theory of cross-cultural interaction in art from North Africa and Syria receive substantial support, which can be seen in the works of the Galilean mosaic center, whose artisans must have relied on this experience to develop their own artistic style.

\section{References}

1. Avissar M. Lod - A Mosaic Floor. Excavations and Surveys in Israel, 1998, no. 17, pp. 169-172.

2. Blanchard M. Repertoire graphique du décor géometrique dans la mosaïque antique. Bulletin de l'Association International pour létude de la mosä̈que antique, Fasc. IV. Paris, 1973. 108 p. (in French).

3. Dunbabin K. M. D. Mosaics of the Greek and Roman World. Cambridge, Cambridge University Press Publ., 1999. 357 p.

4. Ermolaeva E. Ancient Greek Parody "Convivium Atticum" and Mosaics in the Style "Asarotos oikos" ("Unswept Room/Floor”). Maltseva S.; Stanyukovich-Denisova E.; Zakharova A. (eds.). Actual Problems of Theory and History of Art: Collection of Articles, vol. 5. St. Petersburg, NP-Print Publ., 2015, pp. 69-76. Available at: http://dx.doi.org/10.18688/aa155-1-6 (accessed 20 May 2019) (in Russian).

5. Fradier G. Mosaïques romaines de Tunisie. Tunis, Groupe Ceres Production Publ., 2000. 188 p.

6. Hachlili R. Ancient Synagogues. Archaeology and Art: New Discoveries and Current Research. Handbook of Oriental Studies: Section 1; The Near and Middle East (Book 105). Leiden; Boston, Brill Publ., 2013. $802 \mathrm{p}$.

7. Kiplik D. I. Tehnika zhivopisi (Technique of Painting). Moscow, Iskusstvo Publ., 1950. 522 p. (in Russian).

8. Larionov A. Mosaic from Aldborough, Boroughbridge, North Yorkshire: The Problem of Its Authenticity. Maltseva S.; Stanyukovich-Denisova E.; Zakharova A.(eds.). Actual Problems of Theory and History of Art: Collection of articles, vol. 5. St. Petersburg, NP-Print Publ., 2015, pp. 127-136. Available at: http:// dx.doi.org/10.18688/aa155-1-12 (accessed 20 May 2019) (in Russian).

9. Larionov A. I.; Frolov A. P. Afterwords to the Exhibition in Hermitage of Mosaic from the Lod (Israel). Dizain. Materialy. Tehnologia (Design. Materials. Tehnology), 2017, no. 2 (46), pp. 82-85 (in Russian).

10. Lavin I. The Hunting Mosaics of Antioch and Their Sources: A Study of Compositional Principles in the Development of Early Mediaeval Style. Dumbarton Oaks Papers, 1963, vol. 17, pp. 179-286.

11. Leibner U. Settlement and History in Hellenistic, Roman, and Byzantine Galilee: An Archaeological Survey of the Eastern Galilee (Texts and Studies in Ancient Judaism. Book 127). Tübingen, Möhr Siebeck Publ., 2009. $471 \mathrm{p}$.

12. Leibner U. (ed.). Khirbet Wadi Hamam: A Roman-Period Village and Synagogue in the Lower Galilee. Qedem Reports, 13. Jerusalem, Institute of Archaeology, Hebrew University of Jerusalem Publ., 2018. 660 p.

13. Lightfoot C. S. The Roman Mosaic from Lod, Israel. The Metropolitan Museum of Art. Available at: https://www.metmuseum.org/blogs/now-at-the-met/features/2010/the-roman-mosaic-from-lod-israel (accessed 04 September 2018).

14. Magness J. The Huqoq Excavation Project: 2014-2017 Interim Report. Bulletin of the American Schools of Oriental Research (BASOR 380), 2018, pp. 61-131.

15. Miller Sh.; Leibner U. The Synagogue Mosaics. Khirbet Wadi Hamam: A Roman-Period Village and Synagogue in the Lower Galilee. Qedem Reports, 13. Jerusalem, Institute of Archaeology, Hebrew University of Jerusalem Publ., 2018, pp. 144-186.

16. Osband M.; Adan-Bayewitz D.; Asaro F., Glascock M. D. Production Provenances of the Restorable Pottery from a Destruction Level of Mid-Late Hadrianic Date of Wadi-Hamam. Leibner U. (ed.). Khirbet Wadi Hamam: A Roman-Period Village and Synagogue in the Lower Galilee. Qedem Reports, 13. Jerusalem, Institute of Archaeology, Hebrew University of Jerusalem Publ., 2018, pp. 402-415.

17. Panteleev A. D. "Decorative" and "Religious" Statues: Boundaries between Artistic and Religious Components in Graeco-Roman Paganism and Judaism in the Beginning of the Common Era. Zakharova A.; 
Stanyukovich-Denisova E.; Maltseva S. (eds.). Actual Problems of Theory and History of Art: Collection of Articles, vol. 9. Moscow, Lomonosov Moscow State University; St. Petersburg, NP-Print Publ., 2019, pp. 80-89. Available at: http://dx.doi.org/10.18688/aa199-1-8 (accessed 20 December 2019).

18. Piovesan R.; Maritan L.; Neguer J. The Polychrome Sinopia of Roman Mosaic at Lod (Israel): Pigments Characterization and Microstratigraphic Study. $4^{\text {th }}$ International Conference: Progress in Cultural Heritage Preservation (Short Papers). Limassol, Euromed Publ., 2012, pp. 203-208. Available at: https:// www.cut.ac.cy/euromed2012proceedings/shortPapers/203.pdf (accessed 24 September 2018).

19. Rosenthal-Heginbottom R. Dionysos and His Retinue in the Art of Late Roman and Byzantine Palestine. Actual Problems of Theory and History of Art: Collection of Articles, vol. 5. Maltseva S.; Stanyukovich-Denisova E.; Zakharova A. (eds.). St. Petersburg, NP-Print Publ., 2015, pp. 188-194. Available at: http://dx.doi.org/10.18688/aa155-1-18 (accessed 20 May 2019).

Title. Some Observations on the Mosaic Pavements in Lod, Huqoq and Wadi Hamam.

Authors. Larionov, Andrey Iosifovich - Ph. D., professor. Saint Petersburg Stieglitz State Academy of Art and Design, Solianoi per., 13, 191028 St. Petersburg, Russian Federation. larionov.1940@mail.ru

Frolov, Alexandr Petrovich - professor. Saint Petersburg Stieglitz State Academy of Art and Design, Solianoi per., 13, 191028 St. Petersburg, Russian Federation. lubov-frolova@mail.ru

Abstract. As a result of a detailed comparative analysis of individual figurative elements (images of fish) in antique mosaic pavements discovered around the settlements of Huqoq and Wadi Hamam in Lower Galilee, and taking the mode of their execution into account, we can state with certainty that the mosaic panels unearthed in this region are characterized by an unusual stylistic manner, which brings them closer to the pavements from Lod, but makes them starkly different from the ones found in any other area of the late Empire. The evident dissimilarity of these pavements allows us to consider them an isolated group and assume that they were all produced at a single highly creative mosaic center active in Galilee during the $3^{\text {rd }}-5^{\text {th }}$ centuries A.D. Such a conclusion seems logical, no matter which method of scientific analysis is employed.

In the article we detail the technical and technological aspects of making the foundation under the mosaic pavement, and specify the sequence of steps in setting up the layers to secure the durability of the pavement. Of particular importance has been the issue of the underpainting on the nucleus, viewed as a counterpart of today's cartoon, and also to the analysis of the technological process of how the painted ground hidden under the layer of tesserae over it revealed itself in the Lod mosaic pavement.

Keywords: ancient mosaic pavements; underpainting; nucleus; style; tesserae.

Название статьи. Некоторые наблюдения о мозаичных полах из Лода, Хукока и Вади Хамама.

Сведения об авторах. Ларионов Андрей Иосифович - кандидат искусствоведения, профессор. Санкт-Петербургская государственная художественно-промышленная академия имени А. Л. Штиглица. Соляной пер., д. 13, Санкт-Петербург, Российская Федерация, 191028. larionov.1940@mail.ru

Фролов Александр Петрович - профессор. Санкт-Петербургская государственная художественно-промышленная академия имени А. Л. Штиглица. Соляной пер., д. 13, Санкт-Петербург, Российская Федерация, 191028. lubov-frolova@mail.ru

Аннотация. В результате анализа отдельных фигуративных элементов (изображений рыб) на античных мозаиках из Хукока и Вади Хамама в Нижней Галилее мы можем говорить о существовании региональных стилистических тенденций, также очень близких к мозаичному полу из Лода, однако сильно отличающихся от мозаик других территорий поздней Империи. По всей вероятности, эта группа памятников была создана одной выдающейся и продуктивной мастерской в Галилее в III-V вв. н. э. Это подтверждается всеми методами анализа.

В статье рассмотрены технические аспекты создания основания мозаичного пола, уточнена последовательность наложения слоев для прочности покрытия. Особо важным элементом является наличие подмалевка на нуклеусе. Подмалевок можно считать аналогом современного картона. Проанализирован технологический процесс постепенного обнаружения этого подготовительного рисунка под слоем тессер в мозаичном полу из Лода.

Ключевые слова: античные мозаичные полы; подмалевок; нуклеус; стиль; тессеры. 


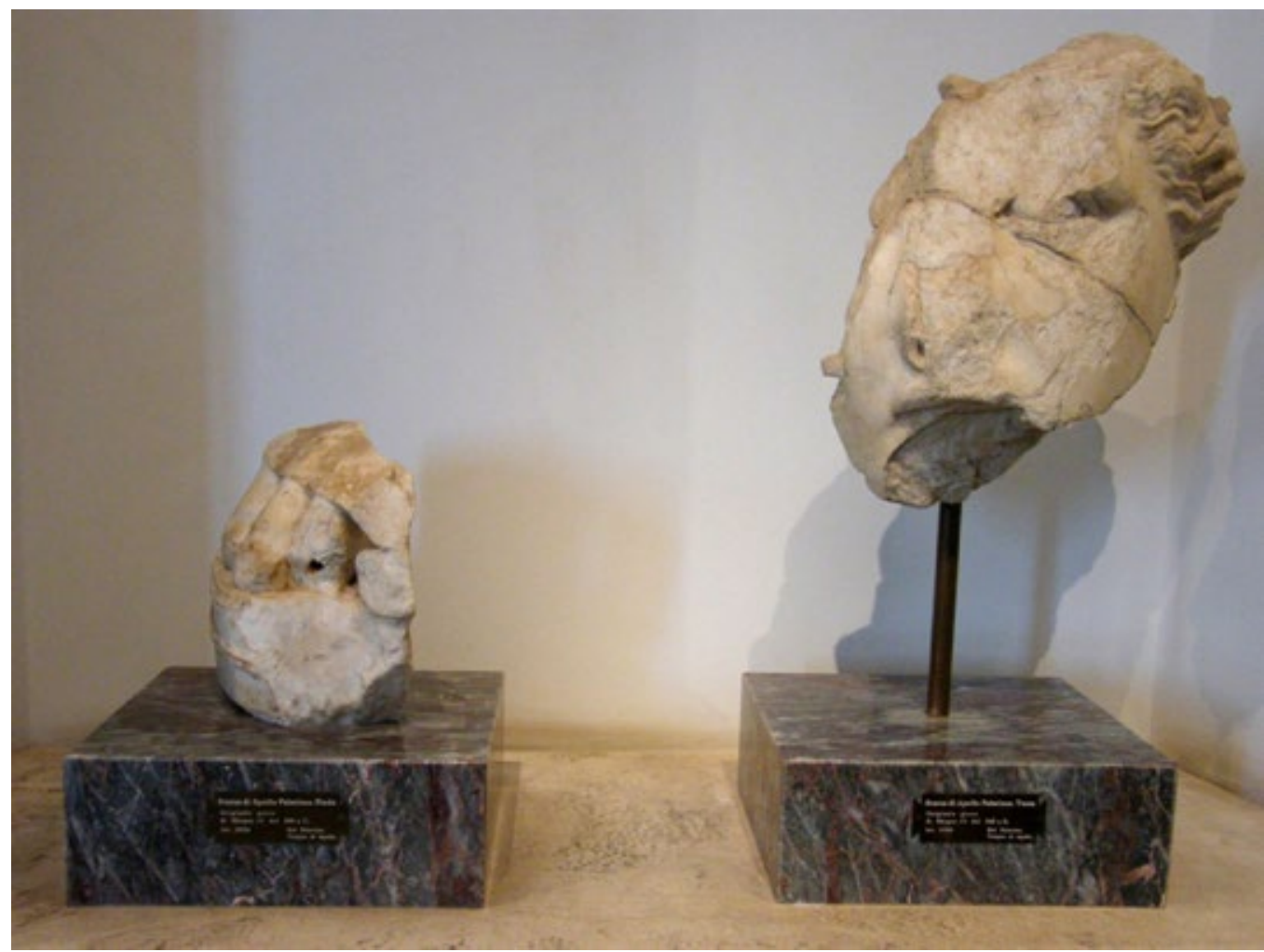

III. 10. Scopas. Head and foot of marble statue of Apollo Rhamnusius. Palatine Museum, Rome. Photo courtesy of Dr. M. A. Tomei

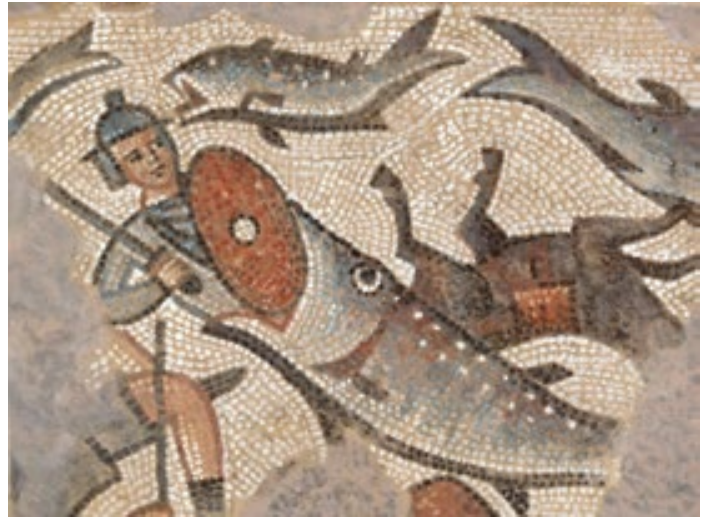

III. 13. The Huqoq mosaic pavement. A scene of an Egyptian warrior who perishes. Sketch by A. P. Frolov

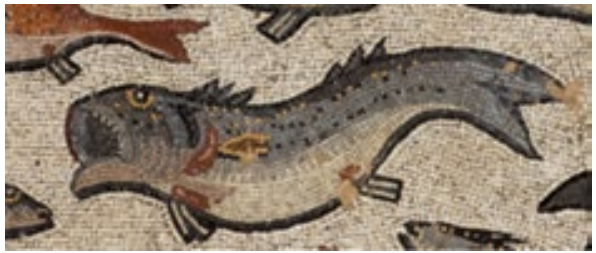

III. 11. The Lod mosaic pavement. A fragment presenting fish

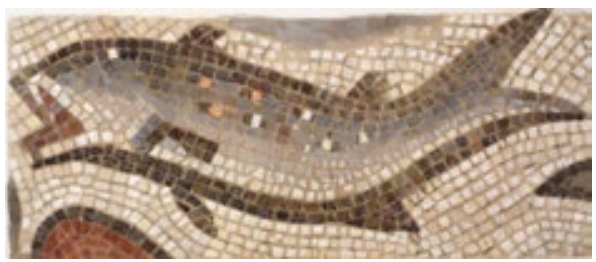

III. 12. The Huqoq mosaic pavement. A fragment presenting fish. Sketch by A. P. Frolov 


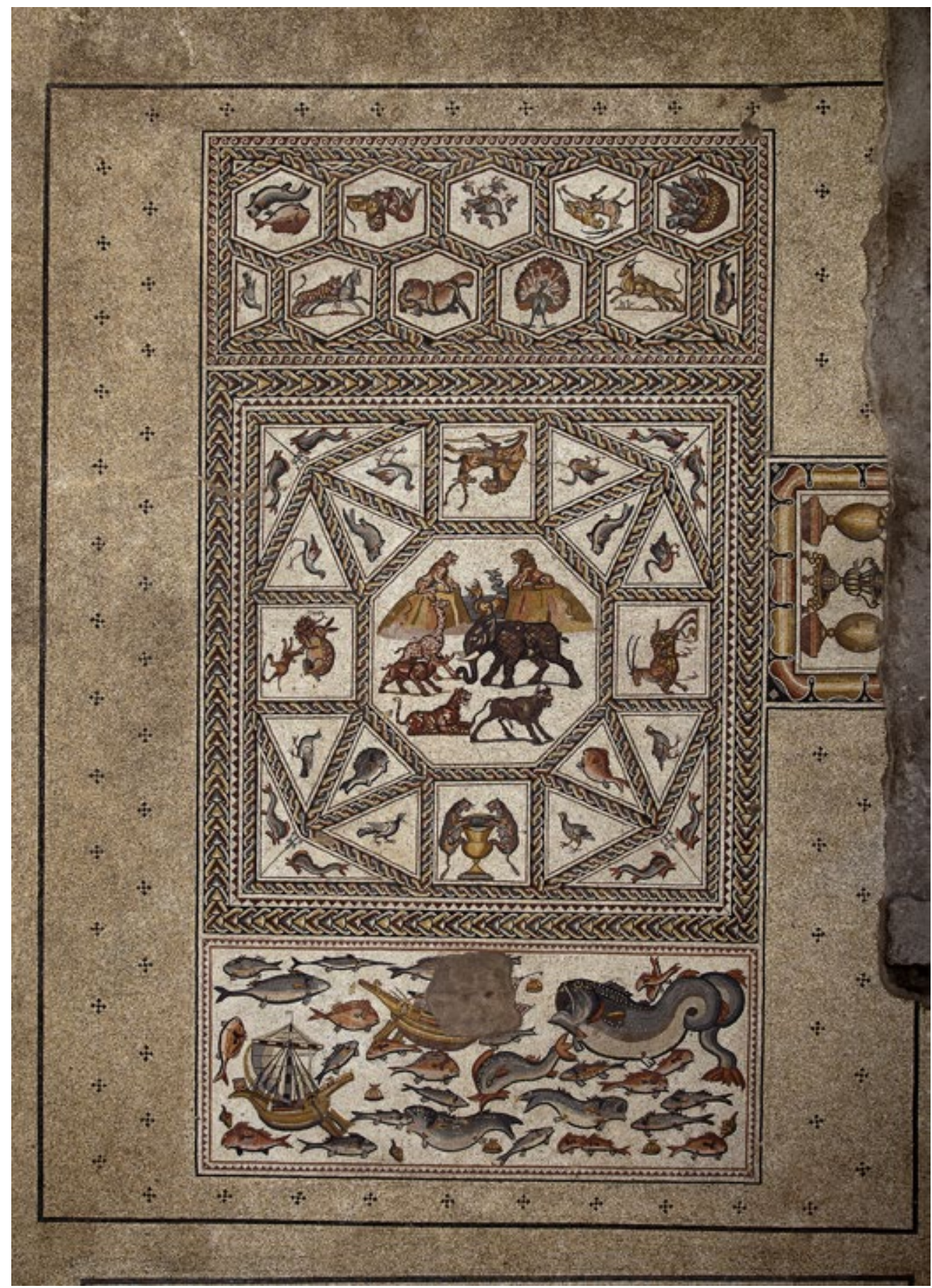

III. 14. The Lod mosaic pavement. Northern part 


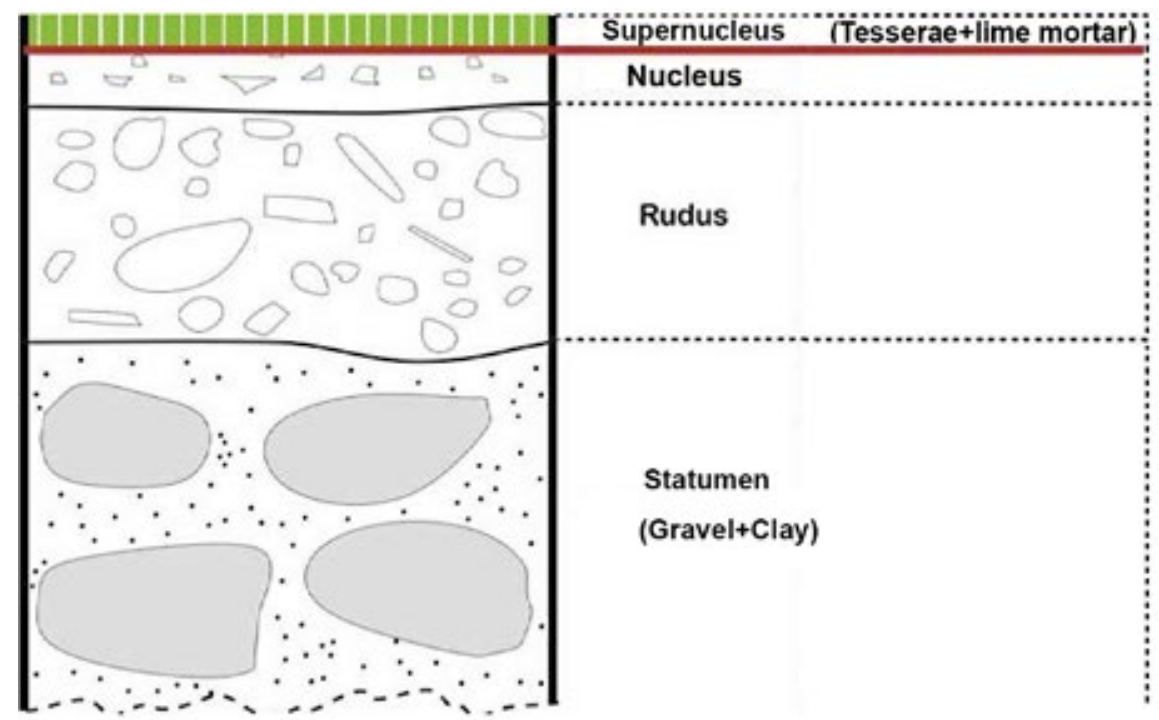

III. 15. Detailed diagram of the Lod pavement stratigraphic section.

Sketch by A. P. Frolov, with the kind permission granted by J. Neguer

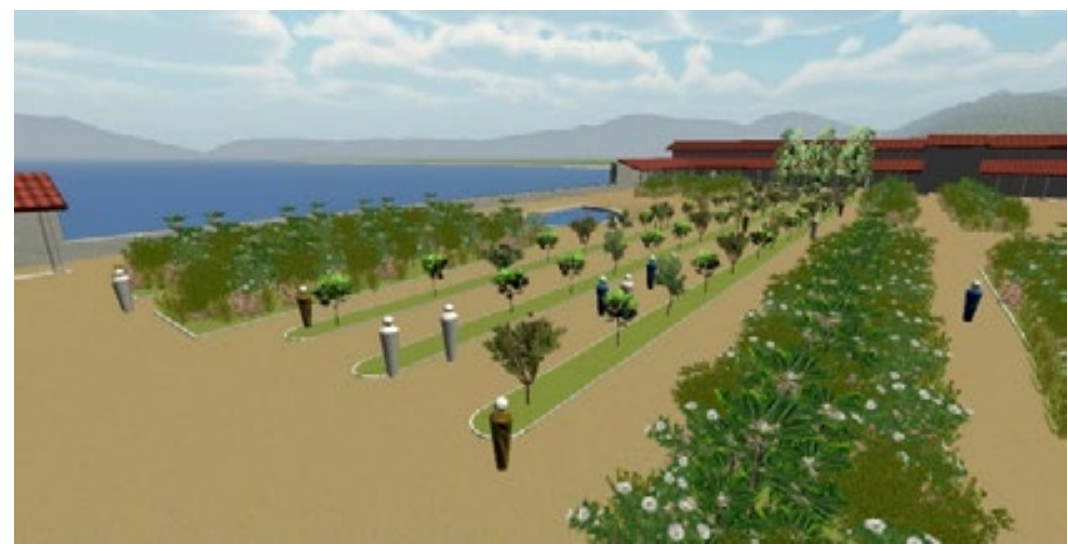

III. 16. Stabiae, Reconstruction of the Garden of the Villa Arianna. RAS Foundation / Prof. K. L. Gleason 